\title{
Regional personal subsidiary farms in the context of the pandemic
}

\author{
Lyubov Borisovna Medvedeva, and Olga Nikolaevna Goncharenko*
}

Federal State Budgetary Educational Institution of Higher Northern Trans-Ural State Agricaltural University, Respublici str. 7, 625003 Tyumen, Russian Federation

\begin{abstract}
The article considers the experience of functioning of personal farmsteads in the agro-industrial region in the context of a pandemic, based on the theoretical positions of outstanding Russian agricultural economists. Based on statistical data, content analysis of regional media and comparative results of the 2016/2021 survey. The main positive phenomena in the development of this sector of the agricultural economy are identified: stable dynamics of development, including at the level of relations between institutional entities. The main problems associated with the lack of awareness of the rural population about the institution of personal farmsteads, the role of cooperation are identified. The obtained results allowed us to draw a conclusion about the need for the work of state and municipal authorities in terms of not only direct state support for personal subsidiary farms, but also education of the rural population.
\end{abstract}

\section{Introduction}

At the present stage of the development of the agricultural sector of the economy, the most important socio-economic significance has been acquired by personal subsidiary farms (LPH) of the population, which are an integral part of all agricultural production, in addition, they serve as a "niche" where unemployed villagers can apply their labor, and are also a form of economic and labor socialization of children and youth. The COVID-19 pandemic, which began in 2020, also made its own adjustments to the functioning of the LPH. This event had a disastrous impact on all spheres of human life. The impact on the social sphere was particularly significant - the current situation in the world required the introduction of quarantine and isolation. The economic sphere was also under the pressure of the pandemic. Companies in many areas of services and production, especially small and medium-sized businesses in the agro-industrial complex, have ceased their activities. The experience of the behavior of small institutional forms of the agricultural industry, in the current circumstances, is significant and relevant.

Conducting research on the state, development and regulation of agricultural enterprises in the conditions of restrictive work formats allows us to determine the most promising ways of their further development in the system of the agro-industrial complex of Russia, taking into account regional peculiarities of functioning, since each region has not only its

*Corresponding author: goncharenko-65@mail.ru 
own climatic and natural features, but also administrative ones that regulate the process of commercial agricultural production, cooperation and state support.

The purpose of our study was to study the practical experience of the functioning and development of regional personal subsidiary farms in the Tyumen region during the pandemic, based on the main provisions of the Russian agricultural economics.

\section{Research methodology}

The object of the study is personal subsidiary farms of agricultural districts of the Tyumen region.

The methodological basis is the structural and functional approach. From the point of view of the structural and functional approach in LPH, as an institution of rural selfemployment, it is possible to distinguish the subject and object of relations, as well as the functions performed by the subjects in the process of implementing these relations.

The subjects of the LPH institute include both the actual institutional subject and the institutional agent. In the case of LPH, this means that in the first case we are talking about primary employment of the population, and in the second - secondary. Moreover, in both cases, the very nature of employment can be both market-based and non-market (selfsufficiency).

Institutional entities (agents) LPH is the entire working-age population, which includes both the economically active and the economically inactive population.

The object of relations between the institutional subjects (agents) in the LPH is the norms and rules regulated by the legislation of the Russian Federation and the regional laws of the subjects of the federation. The informal nature of the relations in the institute of agricultural production is due to the fact that it represents the organization of economic activities within the household. Moreover, economic activity in the LPH is an activity for oneself and for oneself.

The methods of study are: abstract-logical, comparative, the method of sociological survey, economic-statistical, content analysis, and others. When writing the article, a survey was used by the method of formalized interviews with experts in the field of personal subsidiary farms (n-15), whose roles were played by the heads of cooperatives, farmers engaged in the management of personal farmsteads. The survey was conducted in FebruaryApril 2021. To analyze and verify the data obtained from the formalized interview, we used data from sociological surveys in the form of questionnaires conducted by the authors in March-September 2016 [1] in 8 districts of Tyumen region on the questionnaire "Personal subsidiary farms: current state and ways of development", as well as a second questionnaire was carried out in March 2021. The sample population was 400 households. All respondents are residents of rural areas, $22.1 \%$ of the villagers have a private subsidiary farm. At the same time, the majority $(84.9 \%)$ combine work in private households with permanent work in production or in an organization, and a part (16.1\%) are unemployed, but lead a personal subsidiary farm. $57.1 \%$ are female, $42.9 \%$ are male. By education: $34.3 \%$ have higher education, $14.3 \%$ - incomplete higher education, 11.4-technical secondary, $22.9 \%$ - specialized secondary, 17.1-secondary. By social status: $57.1 \%$ consider themselves workers, $20.8 \%$ - employees, 22.1 -peasants. For $71.4 \%$ of respondents, the village is a permanent place of residence, $25.7 \%$ - have lived for more than 10 years, that is, the majority of respondents are indigenous villagers. In order to study the situation in the agricultural sector and new methods of operation of agricultural enterprises during the pandemic, a content analysis of regional Internet publications was carried out for the period from March 2020 to May 2021. 


\section{Research results}

Many well-known agricultural scientists have studied the problems of the formation and development of peasant (farm) farms. Fundamental research in this area was carried out by such scientists as S. N. Bulgakov, V. F. Levitsky, A.V. Chayanov, N. P. Makarov and others. In general, different authors describe two concepts of peasant farming:

1. The concept of a peasant economy as an entrepreneurial economy, in which the owner hires himself as a worker. "The motivation of the peasant entrepreneur is to get the difference between gross income and production costs as a result of investing his capital." This concept of economy is possible "only in the conditions of the capitalist system".

2 . The concept of a peasant economy as a working family economy, in which the family receives a single labor income as a result of spending a year's labor and measures its efforts with the material result obtained. This concept also exists in the conditions of a noncapitalist system. [2]

In our opinion, the agrarian-economic concept of A.V. Chayanov [2], which appeared as a reaction to the new agro - industrial thinking in Russia at the beginning of the twentieth century, which was expressed, on the one hand, in the crisis of the landlord economy, on the other-in the rapid development of peasant farms, is of particular importance for the development of agricultural enterprises in the XXI century. The personal work of the peasant and his family members is put by the scientist at the forefront. So, already in 1911. he gives a classical definition of the purpose of peasant farming: "The task of the peasant labor economy is to provide the means of subsistence to the economic family by making the fullest use of the means of production and labor available at its disposal" [2]. Such management was opposed by scientists to capitalist entrepreneurship based on hired labor. The family and labor economy was not considered separately. In his works, the Russian economist showed the need for cooperation and its inclusion in the national economy. In detail, the scientist dwells on the factors of profitability of peasant farms, which he divides into two groups: intra-economic and national economic.

The greatest attention, Chayanov believed, should be paid to the process of direct restructuring of labor family farms into farms based on the use of wage labor in order to obtain surplus value. A.V. Chayanov [2] associated the development of labor peasant farms in the future with the lack of wage labor and gradual cooperation.

The formation of the views of many Russian researchers of cooperation took place under the influence of Western European representatives of this direction. Among them, first of all, it should be noted R. Owen, S. Fourier, Lassalle, Saint-Simon, G. SchulzeDelich, etc. A significant contribution to the development of the theory of cooperation was made by F. G. Turner, N. I. Sieber, N. P. Balin, K. A. Pozhitnov, V. F. Totomiants, M. I. Tugan-Baranovsky, A.V. Chayanov, and others. He widely expanded and justified the idea of mutual assistance as a universal law for all living P. A. Kropotkin [3], who concluded that one of the newest manifestations of evolutionary forms, through the world law of mutual assistance in the field of economic life, is cooperation and that cooperation leads humanity to the highest form of economic relations. The scientist turned to cooperation and its bearers - cooperatives-as a huge social force capable of taking on major social tasks. The idea of reviving the cooperative movement in the agrarian sphere of Russia was consistently defended by Academician A. A. Nikonov [4], arguing that the lack of a developed system of cooperation in agriculture " does not allow us to solve many economic problems, to protect the peasant from the exorbitant appetites of commercial banks and the state itself, to establish sales, supply, storage, processing and sale of products." At the same time, he noted, "the very idea of cooperation in our country is repeatedly discredited, perverted and vulgarized." 
Modern agricultural economists Pustuev A. L. [5], Miloserdov V. V. [6], Bobysheva I. N., Frolova O. A. [7] argue that at the present stage of economic development, the most stable form of farming in rural areas is personal subsidiary farms. Personal subsidiary farms solve social problems, and are also the main form of employment and income generation in the village. In addition, private farms play an important role in improving the quality of life and improving the health of the population. One of the important factors in the popularity and importance of LPH is that it is in them that environmentally friendly products can be produced by organic farming. Even if there is a low economic benefit from the production of marketable products in LPH, their owners will still keep the production for their own needs. So, based on the theoretical conclusions of outstanding Russian scientists, it can be argued that a personal subsidiary farm is an organizational and legal form of agricultural production based on labor family self - organization and cooperation of small owners. The demand for agricultural land is due to the low standard of living of the rural population at the initial stage, which allows the participants of the economy to meet their needs for basic food products, as well as to have additional income from the sale of surplus agricultural products obtained by their own labor due to the rational use of labor, material and land resources. The special nature of the LPH economy is reflected in the legislation that mediates social relations in rural society. The non-entrepreneurial understanding of the households of the population is enshrined in the Federal Law" On Personal Subsidiary Farming " No. 112-FZ of July 7, 2003, which defines LPH as a form of non-entrepreneurial activity for the production and processing of agricultural products (Article 1).

By the beginning of 2000, the share of households in the total structure of agricultural producers reached almost $50 \%$, this trend of increasing personal subsidiary farms of the population continues at the present time. In total, 190 thousand private households of citizens, more than 900 peasant farms [8] and 115 agricultural consumer, credit and marketing cooperatives were registered in the region in 2016, the share of small businesses in the Tyumen region is $50.5 \%$, and $48.4 \%$ is the share of agricultural organizations in the total volume of agricultural production. According to the results of 2017, more than $47.6 \%$ (36.2 billion rubles) of agricultural products in the region were produced by personal subsidiary farms. Traditionally, the production of potatoes and vegetables prevails. At the same time, the farms of this sector (households of the population, peasant (farmer) farms and individual entrepreneurs) produced of the total production: milk - $48.4 \%$, meat of all types-38.1\%, potatoes $-72.5 \%$, vegetables- $69.7 \%$ [8]. The statistics were confirmed by experts who confirmed that small-scale farming is a significant share of agricultural production in the Tyumen region. Personal farmsteads produce such products, primarily for their own consumption. But the implementation, processing of surplus-these are issues that are important to deal with at the state level. This issue is paid attention in the municipalities, at the level of the regional government. Programs are being developed that encourage residents of the region to develop personal subsidiary farms (LPH), various costs are subsidized, and cooperatives that provide services to the population are supported.

The statistical data is also confirmed by the results of the survey. The most common types of farming, according to the survey of rural residents on the questionnaire "Personal subsidiary farms: the current state and ways of development "(2016 and 2021) are potato farming, $85 \%$ of respondents are engaged in it, vegetable growing- $62 \%$, pig farming- $50 \%$, cattle breeding $-48 \%$, poultry farming $-29 \%$, sheep farming $-23 \%$, collecting wild plants $14 \%$, rabbit breeding $(8.9 \%)$. At the same time, $51 \%$ of respondents noted that they are engaged in LPH "all their life", 38\% - "5-10 years", 11\%- "1-5 years". On average, citizens spend from 2 to 6 hours on maintaining a personal subsidiary farm, depending on the number and number of animals and the size of the land. $72 \%$ of respondents "consume their own products", $23 \%$ - "consume them themselves, help their relatives" and 5\% "grow them for sale". Most of the population is engaged in small and medium-sized farms 
for self-sufficiency in food. The data shows that only $5 \%$ of the respondents surveyed are suppliers of products to the market. Agricultural products are sold independently in the markets $(69.2 \%)$ or through delivery points $(30.8 \%) .86 \%$ of respondents are engaged in the processing of products: $77 \%$ are engaged in vegetable and berry canning, $33 \%$ - meat and fish canning, $31 \%$ - smoking. Only $4 \%$ sell their own processed products.

In the opinion of $74.3 \%$ of the villagers, the costs of small and medium-sized farms pay off, but not in the opinion of $25.7 \%$. More than $70 \%$ of respondents spend no more than 50,000 rubles a year on purchasing products for reproduction. $64 \%$ of respondents say that it is profitable to engage in private farming, because it is a way to provide themselves and relatives with food, provides employment and is partly a source of income. $36 \%$ noted the unprofitability of LPH employment, explaining the high cost of feed and the high labor intensity of the work. In general, according to $51.8 \%$ of respondents, LPH is a profitable, profitable enterprise, both material in the form of products received, partially sold, and social-thanks to relatives and friends. The ecological component of personal subsidiary farms remains unquestionable, as $100 \%$ of respondents prefer organic farming.

Private farms have very low technical equipment, only $25 \%$ of the respondents have any equipment, mainly minitractors, potato diggers, road transport. Only $51.4 \%$ of the respondents have the necessary premises for private housing. Additional labor is used by $20 \%$ of those employed in the LPH, but not permanently, but only during particularly stressful periods of work. It is quite difficult to engage in private farming independently, so according to the respondents, "relatives" - $42 \%$, "the state" - $41 \%$, "the state through the sales assistance system" - 9\%, "the state through the credit system" - 8\% should provide assistance. The villagers are poorly informed about the state support of the LPH. Only $42.9 \%$ of respondents know about it, and only $11.4 \%$ of them actually used it. The villagers consider the development of cooperatives to be an important measure for the development of small and medium-sized enterprises: "credit" - 28.2\%, "supply" - 28.1\%, "sales" - 26.4\%, "service" $-17.3 \%$. Villagers are wary of taking out loans. due to the high interest rate and uncertainty associated with the sale of products and making a profit. Only $34.3 \%$ of respondents used the services of credit institutions.

There was a certain difference in the views of the owners of private farms, which was manifested in 2021, compared to 2016. The majority of respondents (84\%) in 2021 are sure that private farms not only contribute to the stability of the financial situation, but also to the improvement of social status, as it gives the opportunity to realize their abilities in quarantine conditions. In the comments to the questionnaire, 16 people indicated that having their own household helped their families during the pandemic "to feel like fullfledged people: not to be afraid of getting infected, to do without masks." In addition, "the village and rural lifestyle with the onset of a pandemic can be considered a priority compared to the urban one, since the latter leads to crowding and the rapid spread of viral diseases", and the presence of "LPH is always environmentally friendly and healthy products, the ability to exercise mobility in household divisions". If in $201658 \%$ of respondents were ready to move to the city if they found a suitable job, then in 2021 only $27.6 \%$ are ready for such a move. As can be seen from the results of the survey, there have been changes in the views of the villagers, the occupation of private farms has become more socially conscious. The responses of the villagers in 2021 demonstrate the importance of LPH for the development of the family institution, the maintenance of a special national culture [9]. Indeed, the pandemic has affected the development of family-marriage relations. Quarantine and, as a result, the need for round-the-clock presence in the family, as a certain indicator, showed an increase in the number of divorces. In the usual work rhythm, families communicate little, and on vacation they experience positive emotions, while the quarantine was accompanied by negative emotions and not always pleasant communication. After getting to know each other better, a large number of couples decide 
to divorce [10]. Respondents - owners of private farms (100\%), who took part in the survey in 2021, expressed that the family remained their main value and the quarantine did not make any changes, except that children and grandchildren came to the countryside during the quarantine period and spent time with their parents, grandparents. This answer confirms the thesis of V. V. Samsonov [11] that private farms express the most consistent family type of economy, which, in our opinion, affects the strength of the institution of the family, family traditions and values. This shows the kinship of modern personal subsidiary farms with traditional peasant farming, which confirms the correctness of the thesis of A.V. Chayanov that the characteristic property of a peasant farm is a symbiosis of economy, demography and culture, emphasizing that in a working peasant farm, the incentive to work is the needs of the family and the degree of their satisfaction, and the peasant yard is continuously connected with the life of the entire village society and society as a whole.

Content analysis of online publications for the period from March 2020 to May 2021 showed that:

1. In the Tyumen region, the number of enterprises decreased due to the pandemic. A slight decrease in the production indicators of personal subsidiary farms is associated with the all-Russian trend of aging of the population in rural areas and the reluctance of the younger generation to engage in traditional agricultural types of production.

2.Receiving state support during the fight against the pandemic, which fulfilled the main mission - to stabilize the situation, played a major role in the dynamic development of LPH. Support for personal subsidiary farms as important participants in the agricultural production system in the Tyumen region was carried out in sufficient volume, forms of direct and indirect support amounted to almost 300 million rubles. The amount of grants to Agrostartap increased from 3 to 5 million rubles. Grant support was provided to family livestock farms and agricultural cooperatives for the development of the material and technical base. There are also subsidies for peasant (farm) farms for milk production: 2.2 rubles per liter for those who keep livestock; 1.8 rubles per liter - for those who reduce it. For agricultural consumer cooperatives, the rate for reimbursement of the cost of harvesting milk is up to 4 rubles per liter. In addition, it was provided for the reimbursement of part of the costs of agricultural cooperatives for the purchase of property for subsequent transfer (sale) to members of the cooperative, as well as for the purchase of agricultural machinery and equipment for the provision of services to members of the cooperative. All these measures are reflected not only in the stable provision of high-quality and affordable products to the residents of the region, but also in the recognition at regional and federal competitions. One of the last awards was won by Tyumen parmesan. He received a silver medal in the category "Aged cheeses" at the competition "Best Cheese of Russia-2020". More than 170 cheesemakers competed on their own, presenting about 700 samples. The taste qualities of the applicants were evaluated by 80 cheese experts from Russia, France, Switzerland and Belgium. Since 2021, the programs "Agrostartat" and "Novice Farmer" have been replaced by a new program to support farmers "Agroprogress". Today, the state, together with the banking structures, offers farmers not only financial resources, but also knowledge that will help them not only to engage in expanded reproduction, but also to promote their products on the regional market of agricultural products.

3. Cooperative forms of cooperation between small businesses continued to develop. As of 01.10.2018, 89 agricultural consumer cooperatives (excluding credit cooperatives) are operating in the Tyumen region with a total number of shareholders - 6980, including 6793 (98.2\%) citizens of LPH. The revenue of agricultural consumer cooperatives increases annually. For a part of the rural population, private farms often serve as the main and only source of income, so the created system of consumer cooperation helps to solve economic, organizational and production problems. Currently, the services of cooperatives in the region cover about $72 \%$ of rural areas. Through a network of consumer cooperatives, up to 
$90 \%$ of the total volume of milk purchased from the population is purchased, 1.4 thousand tons of meat of all types, 58.1 tons of potatoes and vegetables, services are provided in the amount of 92.6 million rubles.

In this regard, the experience of the Vagaysky and Zavodoukovsky districts is successful. The agricultural production cooperative operating in the territory of the Vagaysky district, according to the expert - head of the cooperative of the Vagaysky district, actively cooperates with LPH in the procurement of milk, potatoes, wild plants, meat, fish, providing services for the procurement of hay, firewood, wood, plowing of vegetable gardens. Participates in the construction of mini-farms. All cooperatives of the district and LPH use loans from the credit cooperative. The expert-deputy head of the agricultural cooperative "Usadba" added that with the competent organization of the cooperative movement, the owners of small farms get on their feet, raise livestock, and sometimes the income from small farms is higher than the salary of workers in the oil and gas industry. Quite active population, according to the interviewed experts, lives in Armizonsky, Zavodoukovsky, Vagaysky, Uporovsky, Vikulovsky districts and others. At the same time, in some territories, interest in the development of animal husbandry is fading, the population is aging, and young people are leaving for the cities. The decline in production activity is noticeable in Sorokinsky, Omutinsky, Tobolsk, and Nizhnetavdinsky districts.

Among the problematic issues identified by respondents in the course of surveys and content analysis, we can distinguish:

1. The lack of legal knowledge in the acquisition of the status of a personal farmstead by the villagers.

2. The appearance of milk powder on the market, the decline in the total consumption of dairy products, and the entry into force of new technical conditions for assessing the quality of raw materials had a significant impact on the fall in the price of raw milk, which created additional problems for those working in private farms. In addition, according to experts, almost a third of the animals in the farm are infected with leukemia. Simultaneously with the spread of the coronavirus infection CAVID-19, cases of avian influenza and African swine fever associated with violations of veterinary rules for keeping animals in private subsidiary farms have become more frequent. The Rosselkhoznadzor Administration for the Tyumen Region, Yamalo-Nenets and Khanty-Mansi Autonomous Okrugs conducted inspections of personal subsidiary farms of citizens engaged in the maintenance and breeding of pigs and birds in the Tyumen region. During the inspections, the following violations of veterinary regulations were revealed:

- isolated paddocks are not equipped for separate keeping of different bird species;

- at the entrance to the pig breeding premises, there are no disinfection mats filled with a disinfectant solution;

- there is no identification of animals;

- the distance from the construction of the wall or corner of the pig breeding room to the border of the adjacent plot is less than 10 meters.

Administrative proceedings under Part 1 of Article 10.6 of the Administrative Code of the Russian Federation were initiated against the owners of LPH. Unfortunately, numerous cases of avian influenza and African swine fever are associated with violations of the veterinary rules for keeping animals in private subsidiary farms. The Department draws attention to the need for strict compliance with the veterinary rules for the maintenance of pigs and birds for their reproduction, cultivation and sale. 


\section{Conclusion}

Thus, the views of agricultural economists, A.V. Chayanov on the development of family peasant farms were justified both at the global and All-Russian, and at the regional level. Personal farmsteads received a second life at the beginning of the XXI century, along with cooperation. Of course, modern personal subsidiary farming is radically different from the peasant farmsteads of the 20 s of the twentieth century, but they have a common feature family self-organization of farming, based on the personal work of the members of the collective. In the Tyumen region, there is a steady positive trend in this segment of the agricultural economy. The study suggests that such farms allow you to survive in difficult conditions of the pandemic. LPH turned out to be the most mobile economic unit.

They not only maintained their production volumes, but also increased them, despite a slight overall decrease in the number of personal farmsteads. An important role in the viability of private farms is played by state support, which is carried out in the region at the proper level. The results of the author's research allowed us to identify a number of interrelated problems of modern personal farmsteads, which can be solved through:

1. Informing the villagers about the state support;

2. Organization of training in the field or remotely on the courses of entrepreneurship, organization of LPH (KFH, etc.).);

3. Establishment of consultation points in the areas of activity (animal husbandry, crop production, plant protection, etc.);

4. Expansion of the cooperative network;

5. Easing of credit conditions;

6. Improvement of territories by creating quarantine herds.

\section{References}

1. O. Goncharenko, L. Medvedeva, Sociology. Economy. Politics, 4, 26 (2017)

2. A. Chayanov, Basic ideas and forms of organization of agricultural cooperation (1919)

3. P. Kropotkin, Mutual assistance as a factor of evolution (2007)

4. A. Nikonov, Agroindustrial Complex: Economics, Management, 7, 26 (19)

5. A. Pustuev, Collection of the international scientific and practical conference. Yekaterinburg: USGA, 47 (2011)

6. V. Miloserdov, Economic problems of stabilization and development of the agroindustrial complex of Russia, 315 (1995)

7. Bobysheva, O. Frolova, Personal subsidiary farms: problems and prospects of development, https://science-education.ru

8. Information on the implementation of the resolution of the Tyumen Regional Duma of 21.11.2013 No. 1548, http://www.duma72.ru

9. N. Khairullina, O. Ustinova, G. Kuchterina, L. Agapitova and L. Medvedeva, Man In India, 96(10), 3949 (2016)

10. B. Noble, and I.N. Sneddon, Phil. Trans. Roy. Soc. London, A247, 529 (1955)

11. B. Kulkova, Human Progress, 6(1) (2020)

12. V. Samsonov. Nikon readings, 195 (2011)

13. N. Biryukova, E3S Web of Conferences, 222, 5013 (2020)

14. M. V. Vinogradova, L. I. Yakobyuk, N. V. Zenina, Espacios, 39(30) (2018) 
15. M. V. Vinogradova, L. I. Iakobiuk, International Transaction Journal of Engineering, Management, \& Applied Sciences \& Technologies, 11(10) (2020) 